Journal of Contemporary Educational Research

Review Article

\title{
Primary Exploration on the Integration and Countermeasures of College Campus Culture and Corporate Culture
}

\author{
Rongcai Wang* \\ Anhui Technical College of Mechanical and Electrical Engineering, Wuhu 241002, Anhui Province, China
}

Funding: "Program of Study Abroad for Young Scholar sponsored by China Scholarship Council" from the 2019

Top Talent Cultivation Project in Universities in Anhui Province (gxgnfx2019099).

\begin{abstract}
College should serve local economy closer, enterprise structure upgrading also improves requirements for personnel, so a collision and integration of college campus culture and corporate culture is accelerating. This paper starts from the relationship explication between the two cultures and the significance explication of their melange, in view of the problem of integration of this two culture, the paper propose five countermeasures: put the essence of enterprise culture into the "3-outlooks" and "3-styles" education, capture the key of two culture integration, establish the main line of integration, integrate college practice education resources, and promote undergraduate innovative and entrepreneurial ability.
\end{abstract}

Key words: College Campus Culture and Corporate Culture; Integration; Countermeasures

Publication date: August, 2020

Publication online: 31 August, 2020

*Corresponding author: Rongcai Wang, ahjdwrc@126. com

\section{Cultural Relevance Analysis between College and Corporation}

Emanated from Western world, the idea of corporate culture belongs to the category of business management theory and is equipped with incentives and cohesion, coordination and restraint, cost saving, education and other functions. Due to the in-depth development of economic globalization and the gradually refined market division of labor, the competition of enterprises has shifted from the competition of resources, corporate capabilities or human capital to the competition of system and culture. What's more, from the aspect of the micro level, the influence of corporate culture on the overall competitiveness of a company is becoming increasingly critical ${ }^{[1]}$. As the total wealth (spiritually and materially) derived from the main body of the campus, the scope of campus culture covers relevant content including material culture, institutional culture, behavioral culture and spiritual culture. As the situation stabilizes in the current state, application-oriented colleges will take the initiative to serve local areas in terms of talent training and employment promotion. In addition, they will realize the alliance through efficient implementation of talent docking with the enterprises. But in this way, there will undoubtedly be some collisions and conflicts between the campus culture that college students have always accepted and the corporate culture under the background of real business affairs. In terms of goal orientation, incentives and constraints, and innovation and creation, the two cultural associations will be deeply reinforced.

\section{Significance of the Culture Integration between College and Corporation}

(1)The integration of college campus culture and corporate culture is of extraordinary benefit to the self-construction and development of colleges. As far as campus culture is concerned, it can maintain a distinctive campus culture by using the strengths and resources of the enterprise. In this way, it can be ensured that colleges and universities can cultivate and transport talents for a long time. In this case, the strong 
spiritual and intellectual resources of students are also the embodiment of the school's core competitiveness. To a certain extent, this comprehensively promotes the multi-angle health optimization of universities ${ }^{[2]}$.

(2) The integration of college campus culture and corporate culture can promote the cultivation of most of the talents who can be qualified for the applied skills of modern enterprises. It can expand the realization channels of talent training, optimize the awareness of most students in employment, and consolidate the competitiveness of college students in the workplace. This has greatly optimized the talent training in our country and contributed to the promotion of local economic and social vitality.

(3) The integration of college campus culture and corporate culture can contribute to the transition from student roles to social workers, promote the smooth transition of students from college to corporation, help adjust college students' psychological expectations, and reduce the cost of human resources for employers. Thereby finally achieve the effect of stabilizing the soft power of the corporation.

\section{Main Problems Occurred During the Culture Integration between College and Corporation}

(1)The integration of college campus culture and corporate culture is of extraordinary benefit to the self-construction and development of colleges. As far as campus culture is concerned, it can maintain a distinctive campus culture by using the strengths and resources of the enterprise. In this way, it can be ensured that colleges and universities can cultivate and transport talents for a long time. In this case, the strong spiritual and intellectual resources of students are also the embodiment of the school's core competitiveness. To a certain extent, this comprehensively promotes the multi-angle health optimization of colleges.

(2)At present, most college graduates basically have more or less corporate culture problems. Because most companies now have more requirements for college graduates, including but not limited to college students' cultural qualities, professional skills, mental outlook, interpersonal communication, and corporate loyalty. Therefore, in order to improve the quality of talents, universities must actively adapt to the needs of enterprises. Generally speaking, application-oriented colleges and universities should take professional ability training as the core element, and integrate the content of ideological and moral, professional ethics, and humanistic quality education modules into the talent training program. While cultivating students' practical skills, such colleges and universities should also pay attention to cultivating students' comprehensive vocational abilities such as innovation, entrepreneurship and learning ability, and enhance the pertinence of vocational quality education, so as to lay the foundation for students to smoothly integrate into the enterprise and reduce the conformation cycle.

(3) As far as college students are concerned, they should pay attention to the way to in-depth study and inheritance of excellent corporate culture. In the transition from ordinary universities to applied universities, first of all, in the process of shifting from theoretical teaching to practical operation to a combination of teaching and internship practice, a series of practical activities should be carried out to strengthen students' understanding of the majors they have learned and outstanding companies in the industry. Cultural recognition and interaction, so that after entering the company, we can quickly understand the core competitiveness and goals pursued by the company, and become the inheritor of corporate culture subtly, laying a solid foundation for achieving corporate performance and realizing personal career development planning.

\section{Countermeasures to the Integration of College Campus Culture and Corporate Culture}

For corporate human resources and college academic staff, both stable quality and targeted training are supposed to more closely integrate. The construction of campus culture and corporate culture reflects the soft power of schools and enterprises. In order to integrate the two to the greatest extent, it is very worthwhile to further explore the specific countermeasures for the integration of college and corporate culture.

(1) Among the "3-outlooks" and "3-styles" series of education in colleges and universities, corporate culture should be effectively integrated as the essence. Building up the correct outlook on the world and life and values are the content of "3-outlooks". And "3-styles" mainly reflected in three areas: the style of ethos, teaching style and the style of study. Corporations also have core values and corporate customs, such as innovation, teamwork, responsibility, customer (people) oriented, etc. Therefore, it is very important to find a corporate culture that is in harmony with the core values and corporate style of the corporation. In the teaching process, teachers should condense the spirit that is compatible with the "3-outlooks" and "3-styles", and guide and train them in the school's rules and 
regulations, academic philosophy, campus environment, classroom teaching and practical activities; In this way, a cultural ecology of intercommunication between schools and enterprises can be formed, and the basic connotation of corporate culture with a sense of the times and universal significance can be spread to students at the ideological level. In addition, it must be emphasized to improve the professional spirit cultivation mechanism, because it helps to promote excellent industrial culture into education, corporate culture into campus, and professional culture into classrooms, realize the popularization of humanities quality courses, and continuously optimize the comprehensive ability of college students.

(2) Institutions are supposed to precisely focus on the key difficulties of school-enterprise cultural integration in order to enhance the effectiveness of the integration. In addition, building a faculty with the teaching mode of dual-initiative is one of the keys to the integration of corporate-college culture. The mode of dual-initiative faculty refers to a faculty with strong education, teaching and practical ability, not only the ability to cultivate innovative and entrepreneurial talents, but also the ability to innovate in science and technology and carry out industry-college-research cooperation. College should adhere to the principle of "corporate-college joint construction", and establish a "mutual education and mutual education" in which both corporate and college parties can work together, send professionals, hire technical positions, train teachers, and solve teaching problems and production technology problems mechanism. In this way, it can continuously improve the technical application ability of professional teachers and stimulate the overall vitality of the "dualinitiative" teaching staff. Another key to the integration of corporate-college culture is to give full play to the main role of students. Students should consciously learn modern business management theory and culture during school, pay attention to the cultivation of practical skills and comprehensive quality, and improve their recognition of corporate culture through familiarity with modern business management systems; make full use of various platforms and carriers to actively improve social adaptation and social practice ability, interpersonal communication and cooperation ability, cultivate the spirit of unity and cooperation, so that after entering the corporation, they can quickly integrate with the business and form a harmonious cooperation atmosphere.

(3) Each party needs to clarify the main line of collegecorporate cooperation of the integration of production and education in order to promote the cultural integration of colleges. Based on the existing resources for running schools inside and outside universities, all parties should further promote college-corporate cooperation, integration of production and education, and build a new mechanism for college-corporate collaborative education. Firstly, college should promote the pilot modern apprenticeship system. Colleges should select superior majors and try out modern apprenticeships with well-known companies. Both schools and enterprises will jointly develop recruitment, training, and employment programs, implement a flexible school system under the alternation of work and study, thereby establishing a school-enterprise joint assessment mechanism and a professional spirit cultivation mechanism to continuously improve the overall quality of apprenticeship students. Secondly, colleges should adopt a group approach to teach or form alliances. Colleges can use the local industrial development plans, face the needs of regional industrial transformation and upgrading, participate in group education or form college alliances, stimulate the vitality of schools, and promote the open sharing of high-quality resources. Thirdly, colleges should strengthen the construction of practical teaching bases. Colleges can rely on group education or college alliances to jointly rebuild and expand the embedded "college-in-factory" and "factory-in-college" that integrate production and teaching functions. Colleges and corporations should jointly cultivate students' professional ethics. At the same time, it cooperates with well-known companies to develop order classes to bring corporate culture into the classroom and cultivate students' professional ability in an all-round way ${ }^{[3]}$.

(4) Expanding the method of college-corporate cultural integration is an important way to improve corporate cultural awareness and identity. First of all, colleges should vigorously explore the training model of internal training + actual skills competition + off-campus internship. Internal training highlights the pertinence of students' vocational skills training, strengthens students' vocational quality training, and makes the main line of vocational skills improvement and professional spirit training more clearly. Through the introduction of various skill competitions into the teaching link, encourage the use of competitions to teach, the integration of teaching, the integration of competitions, and the integration of competitions. By hosting and participating in various skill competitions at all levels, colleges enable college students to experience corporate culture, identify with corporate culture, and enhance the professional characteristics and popularity of colleges. Off-campus internships are divided into short-term off-campus training for each semester and 
on-the-job internships before graduation. Through a comprehensive and detailed understanding of the status quo of the enterprise, students can increase their awareness and sense of identity with the corporate culture, and obtain rational employment. Then, it is also very necessary to actively expand the carrier of quality culture. Colleges should enrich the essence of the carrier of campus culture education, and vigorously highlight the college campus culture with industry enterprise characteristics in talent training, teaching and research, service to the society, and cultural inheritance, so as to integrate into the core value concept of industry enterprises and give full play to the function of corporate culture education, eventually lead students to establish professional ideals based on job training, enhance their skills, serve the masses, and contribute to the society, and cultivate the professional spirit of advocating labor, professionalism, trustworthiness, creation and practicability to the largest extent ${ }^{[4]}$.

(5) The society uses innovation and entrepreneurship to guide the integration of college campus culture and corporate culture. As the name suggests, entrepreneurship is much more valuable than employment, especially in terms of difficulty and profitability. To create a culture of innovation and entrepreneurship, colleges should actively advocate an innovative culture that dares to be the first and tolerates failure. Colleges should deeply analyze the needs of higher education for corporate culture, and strive to create a corporate education situation and atmosphere. Colleges should optimize the innovation and entrepreneurship training system for college students, carry out training and guidance on innovation and entrepreneurship for college students, and train students with strong entrepreneurial willingness to become entrepreneurial "seed players" and "entrepreneurship leaders". By using entrepreneurship to bring employment and strengthening the function of incubators, colleges can attract various types of venture capital, guide and promote the combination of entrepreneurial incubation and the transformation of scientific and technological achievements, and improve the technical support service system. Colleges should continue to improve rules and regulations such as the Administrative Measures for University Students' Science and Technology Innovation Work, and invest special funds to build maker spaces and innovation workshops, provide hardware guarantees for students' innovation and entrepreneurship, and promote professional training rooms and other innovative resources for free to students, in order to provide strong support for the widest possible participation in entrepreneurial activities.

\section{References:}

[1] Li JF, Zhang L. The value and implementation path of school-enterprise cultural integration in applied universities[J]. Applied Higher Education Research, 2017,(4): 20-23.

[2] Yang D. Research on the docking mechanism between campus culture and corporate culture in higher vocational colleges[D]. Dalian University of Technology, 2015.

[3] Li YJ. Research on the Problems and Countermeasures of Enterprise Culture Integration in Higher Vocational Colleges-Taking $\mathrm{H}$ Vocational College as an example[D]. Hebei Normal University, 2018.

[4] Zhou CG, Zhou Jianghu. Analysis on the cultural integration of school and enterprise in higher vocational education[J]. Vocational Education Forum, 2019, (10): 138-142. 